\title{
Applications of quick look methods for evaluating the Middle Miocene Jeribe Formation from a selected well in Jambour Oilfield, Kurdistan Region, northern Iraq
}

\author{
Dler H. Baban ${ }^{1} \cdot$ Asos S. Abdulla ${ }^{1} \cdot$ Hasan M. Omar ${ }^{2}$ \\ Received: 24 August 2017 / Accepted: 24 December 2017 / Published online: 15 January 2018 \\ (c) The Author(s) 2018. This article is an open access publication
}

\begin{abstract}
Quick look methods (QLM) in log interpretation are helpful to the geologist because they provide flags, or indicators, that point to possible hydrocarbon zones. The importance of QLM is in their ability to provide information about the nature of the fluids in the pore spaces and the lithology of the reservoirs in a quick and simple way. Four ways of QLM are applied on the Middle Miocene Jeribe Formation from the well Ja-49 in Jambour Oilfield. The apparent water resistivity $\left(R_{\text {wa }}\right)$ method helped in quick detecting the hydrocarbon-bearing zones of the formation. The logarithmic movable oil plot method assisted in detecting the intensity of the movability of the hydrocarbons within the hydrocarbon-bearing zones of the formation. The $\mathrm{SP}$ versus $R_{\mathrm{xo}} / R_{\mathrm{t}}$ overlay is an additional helpful way for detecting water and hydrocarbon-bearing horizons without need to know porosity. movable hydrocarbon index (MHI) is also used as QLM for detecting the movability of the hydrocarbons through calculating the ratio of water saturation in the uninvaded zone to that of the flushed zone. Accordingly, the formation in the studied well appeared to be generally a hydrocarbon-bearing reservoir with zones of different movable hydrocarbon potentiality. The application of MHI method indicated that about $53 \%$ of the gross $56 \mathrm{~m}$ thickness of the formation contains movable hydrocarbons. The upper and lower $5 \mathrm{~m}$ of the formation appear to be containing the most efficient productive horizons. No actual oil water contact is observed in the studied section of Jeribe Formation, which means the oil column extends down to certain depth in the formations underlying Jeribe Formation.
\end{abstract}

Keywords Jeribe $\cdot$ Jambour $\cdot \log$ analysis $\cdot$ QLM $\cdot$ Kurdistan Region

\section{Introduction}

The Miocene Carbonate Jeribe Formation in Kurdistan Region has effective reservoir properties in most of the old and newly discovered oilfields. The porous and permeable nature of the formation which sometimes enhanced by secondary fracturing or vugging makes the formation act as a very attractive target in the exploration plans of most of the petroleum companies in the region. Obvious examples are the discovered fields in the last few years including Sarqala, Taza, Tawqe (Abdulla 2017; Banks 2011; Ibrahim 2008) and other oilfields in which Jeribe comprised one of their potential reservoirs.

\footnotetext{
Dler H. Baban

dler.mohamad@univsul.edu.iq

University of Sulaimani, Sulaymaniyah, Iraq

2 Kirkuk Oil Training Institute, Kirkuk, Iraq
}

The attraction of Jeribe Formation is not only due to its porous and permeable nature as a reservoir rock, but also due to being deposited in a relatively wide depositional environment and hence existing in most parts of Iraq. Being Jeribe Formation of Middle Miocene in age (Sissakian et al. 2016), so its stratigraphic position in the geologic column of the area gives the formation a great chance to receive the generated oils from all of the known potential source rocks in the region (which are mostly of Jurassic Period). On the other hand, the formation is overlain by the evaporites and clay beds of the most effective seal rocks in the region known as Lower Fars (Fatha) Formation.

In this study, an attempt done to detect some reservoir properties of Jeribe Formation based mainly on the available well log data and by applying the techniques of quick look methods (QLM). The selected well for this application is Ja-49 from the known Jambour Oilfield in which the 56-m-thick Jeribe Formation has been penetrated between depths 2156 and $2212 \mathrm{~m}$ of the well. 
In the techniques of QLM (which are widely used by log analysts for wellsite evaluation), log data are plotted in a reasonably simple and effortless way that reveals different reservoir properties. The selected techniques to be applied in this study are among the basic techniques of QLM which are discussed and mentioned by different authors including Asquith and Gibson (1982), Bateman (1985), Schlumberger (1989), Bassiouni (1994), Krygowsky (2003), Asquith and Krygowski (2004), Serra and Serra (2004), and Johnson and Pile (2006).

\section{Jambour Oilfield}

Jambour Oilfield is located southeast of Kirkuk City on the same axis of Kirkuk, Bai Hassan, and Khabbaz structures (Fig. 1). First exploration well in this field has been drilled in 1927. This giant field consists of a long, narrow, and asymmetrical anticline, about $30 \mathrm{~km}$ long and $4 \mathrm{~km}$ wide having the beds of the southwest limb steeper than the beds of northeast limb (Mohammadamin 1989). It is tectonically located in the Foothill Zone (Hamrin-Makhul Subzone) which belongs to the Folded Zone of the Unstable Shelf (Buday and Jassim 1987).

\section{Jeribe Formation}

The Middle Miocene Sequence in Iraq was deposited in a broad basin following a marine transgression during a phase of strong subsidence that overlapped the margins of the former Oligocene-Early Miocene basin, especially in $\mathrm{NE}$ of Iraq. The sequence consists of a shallow water carbonate (Jeribe Formation) overlying by thick evaporites, carbonate, and marls of the Lower Fars Formation in the intra-shelf area (Jassim and Buday 2006).

The Jeribe Formation was first described by Bellen in 1957 (Bellen et al. 1959) in the type locality near Jaddala Village in the Sinjar anticline in Foothills Zone. In its type section, the thickness of the formation is about $70 \mathrm{~m}$ and composed of recrystallized and dolomitized, mostly massive limestones, in beds 1-2 m thick (Bellen et al. 1959).

The formation is supposed to be of Early Miocene age but later included in the Middle Miocene age due to existence of the Orbulina datum near the base of the Jeribe Formation (Parzak 1974).

The formation's lithology is relatively uniform mainly consisting of different facies of limestone. Some marly limestone and anhydrite sections were also mentioned

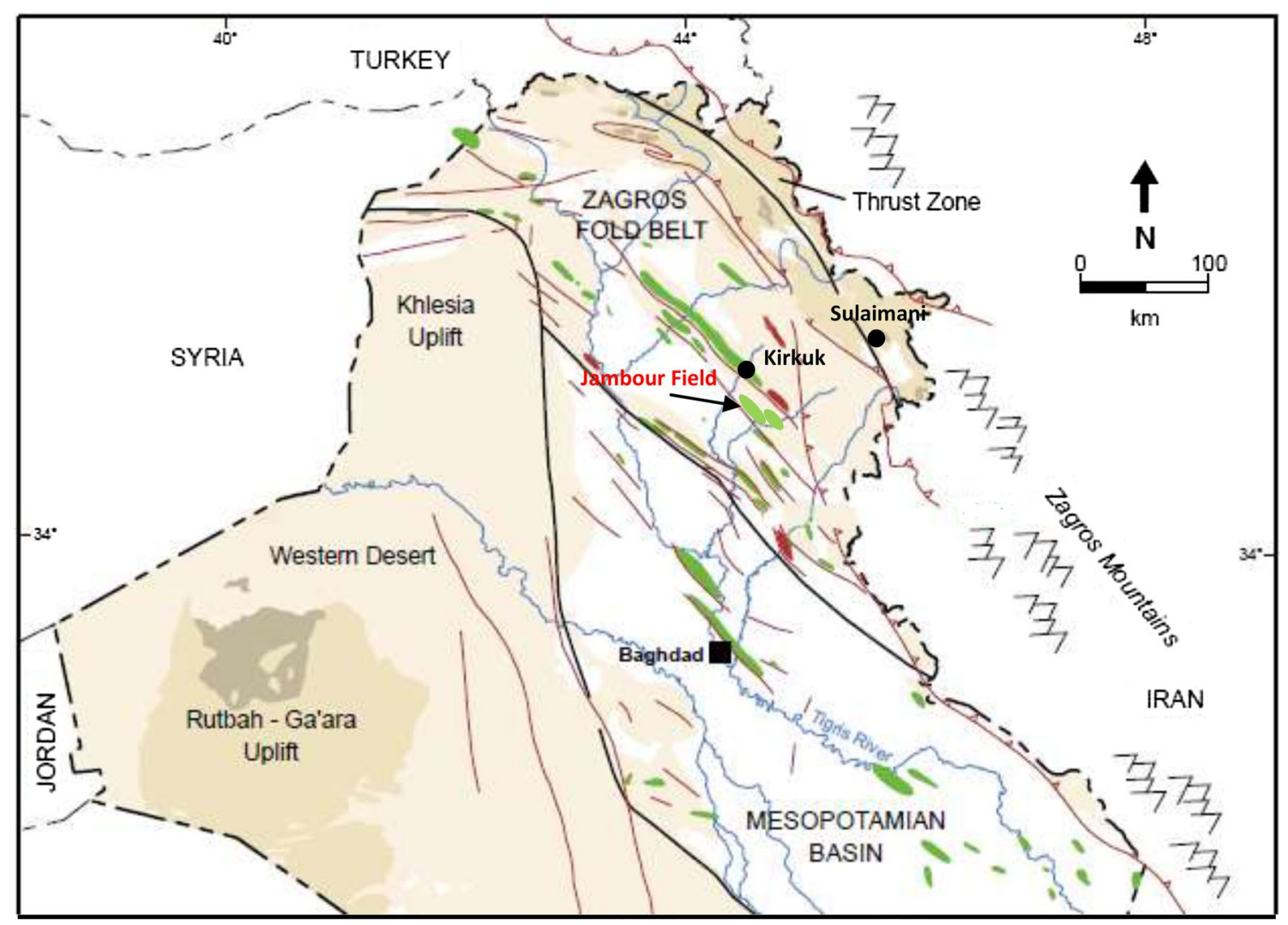

Fig. 1 Location of the studied field of Jambour 
by Johnson (1961; in Buday 1980), Ibrahim (2008), and Baban and Hussein (2016).

The Jerbie Formation was deposited in lagoonal (backreef and reef environment, with sign of more offshore facies too. Reef and back reef are predominant according to Bellen et al. (1959). The formation probably represents a shallowing upward carbonate ramp sequence as it was deposited relatively throughout the basin (Aqrawi et al. 2010).

Jeribe Formation in the studied section consists of about 56-m-thick limestone, dolomitic limestone, and dolostone beds with few narrow beds of anhydrites or anhydritic beds (Fig. 2). Mudstone and wackestone are the dominant microfacies of the formation.

\section{Previous works}

A lot of works done about Jeribe Formation in Iraq. In this section, focus will be only on those works that deal with characterization of Jeribe Formation from reservoir properties point of view.

Sun and Esteban (1994) discussed the reservoir quality of Euphrates and Jeribe formations and mentioned that in central Iraq these carbonate reservoirs have porosities ranging between 10 and $30 \%$ and permeabilities from 1.0 to several hundreds $\mathrm{mD}$ in open marine facies.

Markaryan (2005) studied Jeribe Formation in a number of fields in Dyala Governorate. She has revealed that Jeribe

\begin{tabular}{|c|c|c|c|c|}
\hline $\begin{array}{l}\text { Depth } \\
\text { m }\end{array}$ & Formation & $\begin{array}{c}\text { Thickness } \\
\text { m }\end{array}$ & $\begin{array}{l}\text { Dominant } \\
\text { Lithology }\end{array}$ & $\begin{array}{l}\text { Lithology } \\
\text { Description }\end{array}$ \\
\hline \multirow{2}{*}{1338} & $\begin{array}{l}\text { Upper } \\
\text { Fars }\end{array}$ & 1338 & 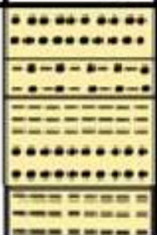 & $\begin{array}{c}\text { Alternations of } \\
\text { sandstone and } \\
\text { claystone }\end{array}$ \\
\hline & $\begin{array}{l}\text { Lower } \\
\text { Fars }\end{array}$ & 673 & 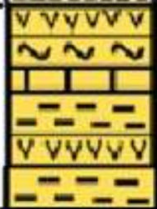 & $\begin{array}{c}\text { Rythmic } \\
\text { alternations of } \\
\text { sandstone, } \\
\text { clalystone, marl, } \\
\text { and evaporites }\end{array}$ \\
\hline \multirow{2}{*}{$\begin{array}{l}2156 \\
2212\end{array}$} & Jeribe & 56 & & $\begin{array}{c}\text { Limestone and } \\
\text { dolomitic limeston }\end{array}$ \\
\hline & Dhiban & 45 & 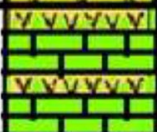 & $\begin{array}{c}\text { Limestone } \\
\text { and evaporites }\end{array}$ \\
\hline \multirow{2}{*}{$\begin{array}{l}2257 \\
2273\end{array}$} & Euphrates & 16 & 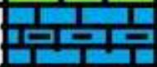 & $\begin{array}{l}\text { Chalky } \\
\text { limestone }\end{array}$ \\
\hline & Serikagni & 27 & 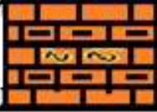 & $\begin{array}{c}\text { Chalky and } \\
\text { marly limestone }\end{array}$ \\
\hline
\end{tabular}

Fig. 2 Stratigraphic section for the well of Ja-49, Jambour Oilfield
Formation has good reservoir properties with an average porosity about $20 \%$ and average permeability about $30 \mathrm{md}$. She examined the porosity type in the formation and mentioned that intraparticle, fracture, channels, vugs, and moldic types all are exist in the formation.

Jassim and Al-Gailani (2006) mentioned that Jeribe Formation has a mean porosity about $17 \%$ and a mean permeability about $200 \mathrm{mD}$. They also noted that in packstone facies of Jeribe Formation, dolomitization creates a mean porosity about $23 \%$ and a mean permeability about $10 \mathrm{mD}$.

Ibrahim (2008) studied Jeribe Formation from sedimentology and reservoir characterization points of view in two wells of Tawke Oilfield in Kurdistan Region, northern Iraq. He concluded that Jeribe Formation belongs to the Miocene Langhian subcycle and composed mainly of limestone and dolomite with thin interbeds of anhydrite. He also identified a number of microfacies within the formation and described the types of porosity existed in the formation including fractures, vugs, interparticles, and intercrystallines.

Al-Ameri et al. (2011) have studied the hydrocarbon in the Middle Miocene Jeribe Formation in a number of oilfields in Dyala district, northern Iraq. They have explored that Jeribe Formation owns an average porosity about $12-27 \%$ in the studied oilfields.

The facies, depositional environment, and diageneses of Jeribe Formation have studied by Al-Dabbas et al. (2012) in selected wells in northern Iraqi oilfields (Ajeel, Hamrin, Judaida, and Khashab). They have identified a number of microfacies with variety of diagenetic processes such as compaction, dissolution, cementation, neomorphism, dolomitization, anhydritization, and silicification.

In Ajeel Oilfield, Gharib (2012) has studied Jeribe and Euphrates formations from a number of wells. He has divided Jeribe Formation using log and microfacies data into two reservoir units separated in the middle part by a marl bed.

The sedimentological and reservoir characteristics of Jeribe Formation have studied by Fadhil (2013) in Allas dome of Hamrin Oilfield, northern Iraq. She has recognized four main microfacies within the formation representing depositional environments from semiclosed platform to open platform and front slope. Then, she has divided Jeribe Formation into two reservoir units ( $\mathrm{A}$ and $\mathrm{B}$, depending mainly on log data) which have separated by a layer of shale. Later she has noted that Jeribe has porosities ranging between 0 and $33 \%$.

Hussein (2015) and Baban and Hussein (2016) studied the Tertiary reservoir (including Jeribe Formation) from a number of wells in Khabbaz Oilfield. Poor permeability due to relatively high content of dispersed shale was the most noticeable conclusion of those two studies.

Al-Jwaini and Gayara (2016) studied the Jeribe Formation in the two fields of Bai Hassan and Khabbaz. They 
characterized the types of the microfacies in the formation and the types of the porosities with the diagenesis affected the properties of the formation. The formation also was evaluated depending on the log data from which shale content, porosity values, and saturations in Jeribe Formation were determined in the two mentioned fields.

Saeed (2017) studied in detail the reservoir characterization of the Jeribe Formation from three selected wells in Hamrin Oilfield. He subdivided the formation to four reservoir units depending on variations in the shale content, porosity, and permeability. He also calculated the net-togross reservoir and pay ratios for Jeribe Formation in the studied wells using different calculated cutoff values for shale content, porosity, permeability, and water saturation.

\section{Quick look methods (QLM)}

According to Asquith and Gibson (1982), quick look methods (QLM) in log interpretation are helpful to the geologist because they provide flags, or indicators, that point to possible hydrocarbon zones requiring further investigation. The importance of QLM is in their ability to provide information about the nature of the fluids in the pore spaces and the lithology of the reservoirs in a quick and simple way.

Before water saturation is calculated for any zone, it is necessary to scan a log and locate favorable zones that warrant further investigation. This is true not only for potential hydrocarbon-bearing zones, but water-bearing zones as well. This is often referred to as "scanilizing" a log (HLS 2007). There are certain responses that should be looked for, and these responses may indicate whether a zone is water bearing or hydrocarbon bearing.

Generally, there are three branches for quick look analysis as mentioned by Bateman (1985) which are compatible overlays of logs, crossplot of selected log readings, and simple algorithms for calculators.

\section{Results and analysis}

In this study, four techniques of QLM selected to be applied for preliminarily characterizing Jeribe Formation. Details of each technique with the obtained results are shown below.

\section{$R_{\text {wa }}$ Method}

This technique is one of the QLM in log analysis mentioned by different authors (Asquith and Gibson 1982; Bateman 1985; Schlumberger 1989; Asquith and Krygowski 2004).

Based on Archie's assumption, the apparent formation water resistivity $\left(R_{\text {wa }}\right)$ is equal to true resistivity $\left(R_{\mathrm{t}}\right)$ divided by formation factor $(F)$. In any clean water-bearing zone
( $\left.S_{\mathrm{w}}=100 \%\right)$, the wet resistivity $\left(R_{\mathrm{o}}\right)$ is equal to $R_{\mathrm{t}}$ and equal to $F$ multiplied by formation water resistivity $\left(R_{\mathrm{w}}\right)$; in such a case also $R_{\mathrm{wa}}$ becomes equal to $R_{\mathrm{w}}$. So, by following variations in the calculated $R_{\text {wa }}$ values along any reservoir, one can detect water-bearing zones and that by following the zones of the lowest computed $R_{\text {wa }}$ values (regardless the magnitude of the of $R_{\mathrm{wa}}$ as ohm m values). In fact, zones of lowest $R_{\mathrm{wa}}$ values will represent either water-bearing zone or zones of lowest hydrocarbon saturations. Accordingly, any increase in the $R_{\mathrm{wa}}$ values will positively proportion to the hydrocarbon saturation.

Through following the plotted curve of $R_{\text {wa }}$ (Fig. 3), it is so easy to notice zones in which lowest recorded values of $R_{\text {wa }}$ are locate (locations of the black arrows in Fig. 3). Those zones are expected to be water-bearing zones or zones with the lowest hydrocarbon saturation. Accordingly, zones with greater computed $R_{\text {wa }}$ values are zones of higher hydrocarbon saturation.

\section{Logarithmic Movable Oil Plot Method}

In this technique of QLM which considered as compatible overlays method, three curves are plotted on a logarithmic scale and their overlying pattern is followed to detect locations of the water- or hydrocarbon-bearing zones in addition to roughly detect the ratio of the movable hydrocarbons.

To apply this technique, values of wet resistivity $\left(R_{\mathrm{o}}\right)$ are needed and the resistivity values of the flushed zones $\left(R_{\text {хоо }}\right.$, considering complete flushing of the zones by mud filtrate) in addition to the true resistivity values of the uninvaded zone $\left(R_{\mathrm{t}}\right)$.

For calculating $R_{\mathrm{o}}$ values, which is the resistivity of the water-bearing uninvaded zone, the simple equation of $R_{\mathrm{o}}=F \cdot R_{\mathrm{w}}$ applied, whereas $F$ multiplied by $R_{m f}$ used for calculating $R_{\text {xoo }}$.

As shown in Fig. 3, the $R_{\mathrm{o}}$ curve is mostly of the lower resistivity value due to being the reservoir water of saline nature and conductive. On the other hand, the $R_{\mathrm{t}}$ curve shows higher resistivity values in most of the zones and becomes close or of the same value with $R_{\mathrm{o}}$ in few zones.

As a QLM, any separation between the $R_{\mathrm{o}}$ and $R_{\mathrm{t}}$ curves is an indication to hydrocarbon-bearing zones, whereas nonseparation cases are indications to water-bearing zones. The space between the two curves is proportion to the percentage of the hydrocarbon saturation.

The benefit of plotting $R_{\text {xoo }}$ curve with the two curves of $R_{\mathrm{o}}$ and $R_{\mathrm{t}}$ is to show preliminarily the ratio between the residual and the movable hydrocarbons. The spacing between $R_{\mathrm{o}}$ and $R_{\text {xoo }}$ represents the residual hydrocarbons, whereas the spacing between the $R_{\text {xоo }}$ and $R_{\mathrm{t}}$ represents the movable hydrocarbons.

By comparing $R_{\text {wa }}$, with $R_{\mathrm{o}}, R_{\text {xoo }}$, and $R_{\mathrm{t}}$ curves (Fig. 4), the following points can be observed: 


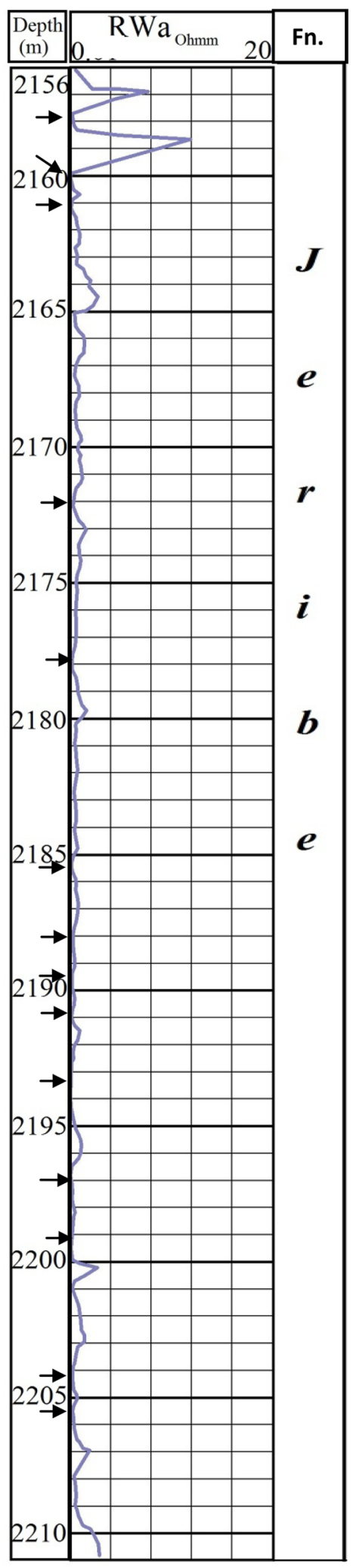

Fig. $3 \mathrm{R}_{\mathrm{wa}}$ presentation as QLM for determining water- and hydrocarbon-bearing zones for Jeribe Formation in the well Ja-49 (black arrows are water-bearing or lowest hydrocarbon-bearing horizons)

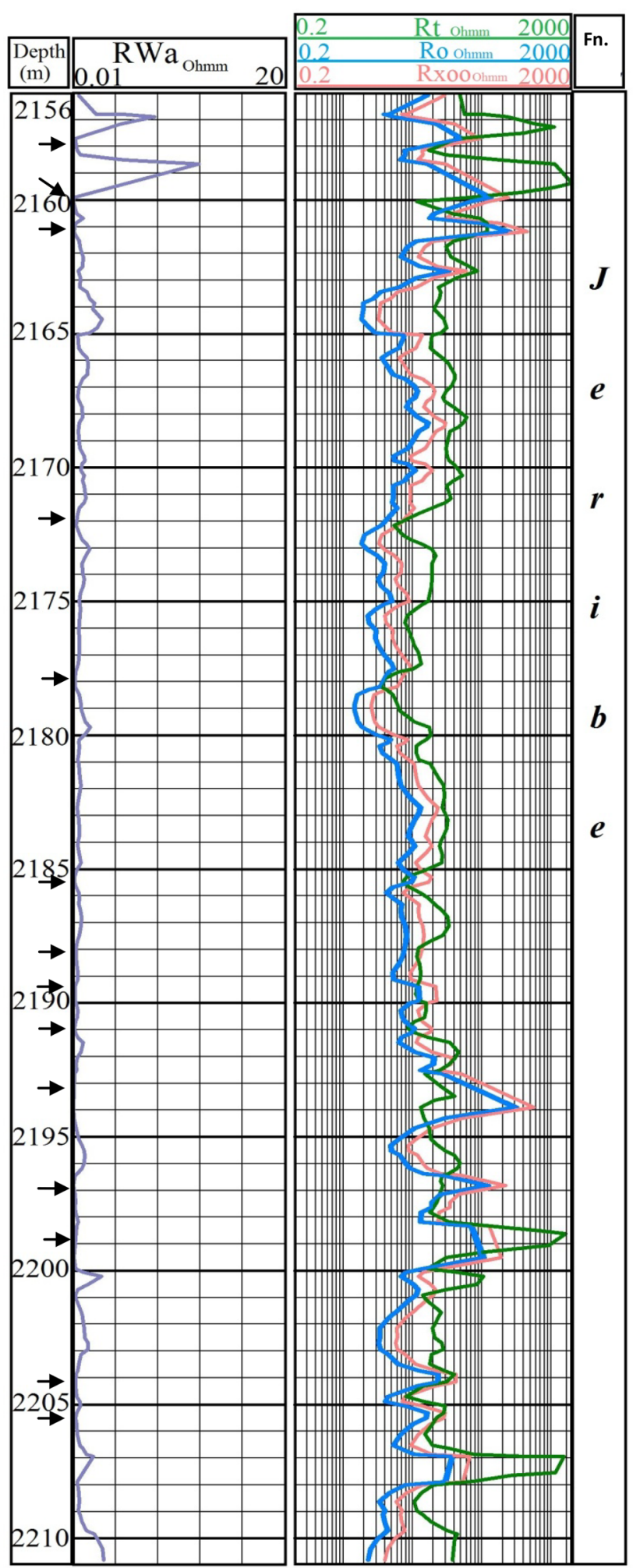

Fig. $4 \mathrm{R}_{\mathrm{wa}}$ and $\mathrm{R}_{\mathrm{o}}, \mathrm{R}_{\mathrm{xoo}}$, and $\mathrm{R}_{\mathrm{t}}$ presentation as QLM for determining water- and hydrocarbon (residual and movable)-bearing zones for Jeribe Formation in the well Ja-49 (black arrows are water-bearing or lowest hydrocarbon-bearing horizons) 
1. In most, but not all the depth intervals the curves show the same result about the containing fluids and their relative saturations.

2. The intervals of high $R_{\text {wa }}$ values showed high recorded $R_{\mathrm{t}}$ values (and vice versa) indicating the workable of the $R_{\text {wa }}$ technique in detecting hydrocarbon-bearing zones in this study (e.g., depths 2156-2158, 2164.5, 2200.5, $2207 \mathrm{~m}$ )

3. Zones of high recorded $R_{\mathrm{t}}$ values are not necessarily zones of high hydrocarbon saturations because low porosity and dense lithology both are causing high recorded $R_{\mathrm{t}}$ values just like hydrocarbons.

4. The high difference between the resistivity of the formation water and the resistivity of hydrocarbons may result in high separation between the calculated $R_{\mathrm{o}}$ and the recorded $R_{\mathrm{t}}$ curves regardless to the water or hydrocarbon saturations ratio.

5. Zones of high water saturation show higher $R_{\mathrm{o}}$ and $R_{\text {xoo }}$ values than the recorded $R_{\mathrm{t}}$ (e.g., depths $2161,2189.5$, 2193-2194, $2197 \mathrm{~m}$ ).

6. The intercalated of water-saturated horizons between the oil-bearing intervals of Jeribe Formation is due to the micropore size of high capillary pressure of those horizons (mostly of Wackestone microfacies) in which the buoyancy force of the migrated oil cannot displace the pore waters.

7. No continuous water-bearing zone is observed in the studied well, which means the oil water contact location is at a greater depth and the whole thickness of Jeribe Formation comprises part of the oil column.

\section{SP with $R_{\mathrm{xo}} / R_{\mathrm{t}}$ overlay Method}

This QLM can be applied in those wells which drilled with freshwater base mud in reservoirs having saline pore water. In such a well condition, good SP log data can be obtained which is commonly helpful in determining the permeable zones where electron exchanges can much easily occur. The main purpose in applying this method is to detect preliminarily the hydrocarbon-bearing zones without need to know porosity. The needed data besides SP are true resistivity $\left(R_{\mathrm{t}}\right)$ and shallow resistivity $\left(R_{\mathrm{xo}}\right)$. The theory behind the method as clarified by Bateman (1985) depends on Archie's equation and the SP relationship (Eq. 1).

$\mathrm{SP}=-K \log \left(R_{\mathrm{mf}} / R_{\mathrm{w}}\right)$

where $\mathrm{SP}=$ spontaneous potential, $\mathrm{K}=$ kelvin, temperature, $R_{\mathrm{mf}}=$ resistivity of mud filtrate, $R_{\mathrm{w}}=$ resistivity of formation water.

By writing Eq. 1 for both invaded and uninvaded zones (Eqs. 2, 3), the formation factor $(\mathrm{F})$ including porosity eliminates (Eq. 4). So, no need to know porosity, cementation factor (m), and tortuosity factor (a) for the reservoir under consideration.

$S_{\mathrm{w}}^{n}=F \times R_{\mathrm{w}} / R_{\mathrm{t}}$

$S_{x o}^{n}=F \times R_{m f} / R_{x o}$

$\left(S_{w} / S_{x o}\right)^{n}=R_{w} / R_{m f} \times R_{x o} / R_{t}$

According to Bateman (1985) and by assuming $S_{\mathrm{xo}}=S_{\mathrm{w}}^{1 / 5}$, then $\left(S_{\mathrm{w}} / S_{\mathrm{xo}}\right)^{n}$ can be replaced by $S_{\mathrm{w}}^{8 / 5}$ in case the saturation exponent $(n)$ assumed to be equal to 2.0. Finally, SP can be represented by Eqs. 5 or 6 .

$-S P=K \log \left\{\left(R_{x o} / R_{t}\right) S_{w}^{5 / 8}\right\}$

or

$-S P=K \log \left(R_{x o} / R_{t}\right)+K \log S_{w}^{5 / 8}$

In wet zones where water saturation is equal to $100 \%$, the part $\mathrm{K} \log S_{\mathrm{w}}^{5 / 8}$ of Eq. 6 is equal to zero, and thus, -SP numerically becomes equal to $\mathrm{K} \log \left(R_{\mathrm{xo}} / R_{\mathrm{t}}\right)$. On the other hand, in hydrocarbon-bearing zones where $S_{\mathrm{w}}$ is less $100 \%$, the part $\mathrm{K} \log \mathrm{S}_{\mathrm{w}}^{5 / 8}$ numerically becomes less than -SP (due to being $\log S_{\mathrm{w}}^{5 / 8}$ less than 1.0). Accordingly, by drawing the two curves of SP and $\mathrm{K} \log \left(R_{\mathrm{xo}} / R_{\mathrm{t}}\right)$, they will track in wet zones and separate in hydrocarbon-bearing zones.

Bateman (1985) supported the application of this method by an example from a sandstone reservoir with a very clear tracking and separation curves of SP and $\mathrm{K} \log \left(R_{\mathrm{xo}} / R_{\mathrm{t}}\right)$ in wet and hydrocarbon-bearing zones, respectively.

In this study, we tried to be sure about the applicability of this technique in more complex carbonate nature reservoirs like Jeribe Formation. Figure 5 shows the overlay of SP and $\mathrm{K} \log \left(R_{\mathrm{xo}} / R_{\mathrm{t}}\right)$ for Jeribe Formation in the well Ja-49. By comparing Fig. 5 with the previously identified depths of the water and hydrocarbon-bearing horizons (Figs. 3, 4), good matching can be observed between both. Although the tracking and separation between the two curves in Fig. 5 are not ideal, it is clear that in hydrocarbon-bearing zones the value of $\mathrm{K} \log \left(R_{\mathrm{xo}} / R_{\mathrm{t}}\right)$ is greater than -SP (positive separation), whereas in water-bearing horizons they are either equal or the value of $\mathrm{K} \log \left(R_{\mathrm{xo}} / R_{\mathrm{t}}\right)$ is less than -SP (negative separation).

\section{Movable Hydrocarbon Index (MHI) Method}

Water saturation of the uninvaded zone $\left(S_{\mathrm{w}}\right)$ and flushed zone $\left(S_{\mathrm{xo}}\right)$ can be used as an indicator of hydrocarbon moveability. If the value of $S_{\mathrm{xo}}$ is much larger than $S_{\mathrm{w}}$, then hydrocarbons in the flushed zone have probably been moved or flushed out of the zone nearest the borehole by the invading drilling fluids. 


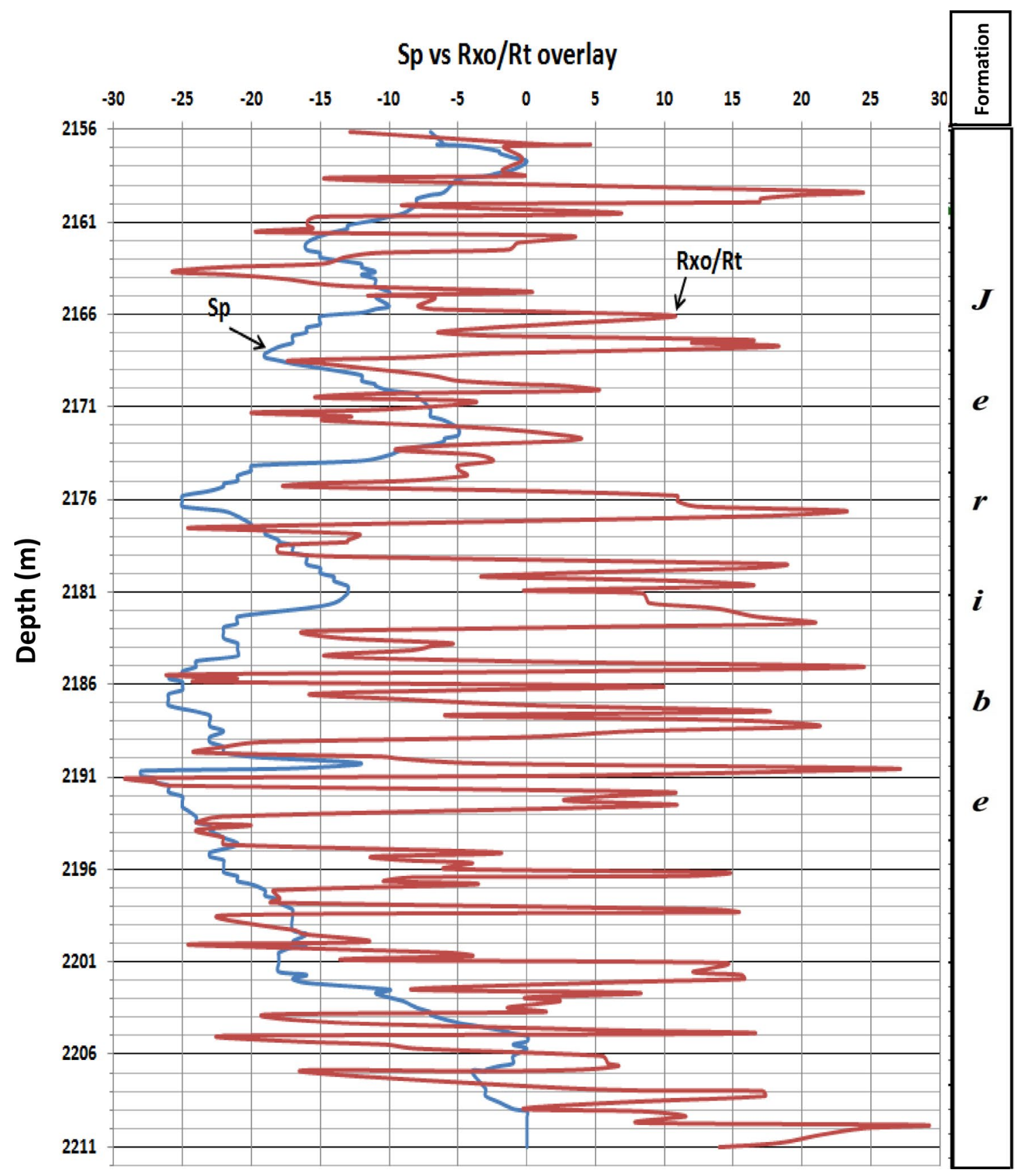

Fig. 5 SP versus $R_{x o} / R_{t}$ overlay as a QLM for Jeribe Formation in the well Ja-49

The ratio method for identifying hydrocarbon moveability bases on the difference between water saturations in the flushed zone $\left(S_{\mathrm{xo}}\right)$ and the uninvaded zone $\left(S_{\mathrm{w}}\right)$. When the water saturation in the uninvaded zone from Archie's equation (Archie, 1942) is divided by the water saturation in the flushed zone, the result is representing MHI as shown in Eq. 7.

$\frac{S_{w}^{2}}{S_{x o}^{2}}=\left[\frac{S w}{S x o}\right]^{2}=\frac{F^{*} \frac{R w}{R t}}{F^{*} \frac{R m f}{R x o}}=\frac{\frac{R w}{R t}}{\frac{R m f}{R x o}}=\frac{\frac{R x o}{R t}}{\frac{R m f}{R w}}$ where $S_{\mathrm{w}}=$ water saturation in the uninvaded zone, $S_{\text {xo }}=$ water saturation in flushed zone, $F=$ formation factor, $R_{\mathrm{t}}=$ resistivity of uninvaded zone (deep reading $\log$ ), $R_{\mathrm{xo}}=$ resistivity of flushed zone (shallow reading zone), $R_{\mathrm{mf}}=$ resistivity of mud filtrate, $R_{\mathrm{w}}=$ resistivity of formation water.

When Sw divides by $S_{\text {xo }}$ (Eq. 7), formation factor $(F)$ cancels out, which means it is no longer necessary to know porosity or a value for the cementation exponent $(m)$ to 
determine water saturation (Asquith and Gibson 1982; Asquith and Krygowski 2004).

Schlumberger (1989) reported that if the ratio of $S_{\mathrm{w}} / S_{\text {xо }}$ is 1.0 or greater, no hydrocarbons are moved during invasion. This is true regardless of whether or not the zone contains hydrocarbons. Whenever the ratio of $S_{\mathrm{w}} / S_{\mathrm{xo}}$ is less than 0.7 for sandstone and less than 0.6 for limestone, movable hydrocarbons are indicated. If carbonate reservoir has a MHI less than 0.6, hydrocarbons are present and the reservoir has enough permeability so that hydrocarbons have been moved during the invasion process by mud filtrate (Asquith 1985).

The calculated MHI values for Jeribe Formation in the studied Ja-49 are presented as curve in Fig. 6. In the same figure, the MHI value of 0.6 used as a cutoff value for separating zones of movable hydrocarbons from zones of nonmovable hydrocarbons (due to being Jeribe Formation of carbonate nature).

The following points are general notes about the calculated MHI values which represents effective movable hydrocarbon zones for Jeribe Formation as appears in Fig. 6:

1. Nearly, the whole Jeribe Formation contains hydrocarbons but practically not all the formation's parts contain effective movable hydrocarbons.

2. Production of hydrocarbons can be expected only in those horizons which showed MHI values less than 0.6.

3. No continuous movable hydrocarbon interval of greater than $4.0 \mathrm{~m}$ thickness found in the studied well.

4. The upper and lower $5 \mathrm{~m}$ of the formation appear to be containing the most efficient productive horizons.

5. Based on the technique of MHI, about $30 \mathrm{~m}$ from the gross $56 \mathrm{~m}$ of Jeribe Formation in the studied well is productive. To be considered as commercially productive horizons, the porosity and permeability of those intervals should be of appreciable values combined with high reservoir pressure.

\section{Conclusions}

The used QLM of $R_{\text {wa }}, R_{\mathrm{o}}, R_{\text {xoo }}$, SP versus $\left(R_{\mathrm{xo}} / R_{\mathrm{t}}\right)$, and MHI are actually fast and practical ways for preliminarily evaluating reservoirs. They provide good indications about the type of the reservoired fluids, their saturations, and movability of hydrocarbons. The application of the QLM in the well Ja-49 showed that Jeribe Formation contains a lot of hydrocarbonbearing horizons. The application of MHI method indicated that about $53 \%$ of the gross $56 \mathrm{~m}$ thickness of the formation contains movable hydrocarbons. More investigations are needed to make sure about whether those horizons can produce hydrocarbons commercially or not. No actual oil water contact is observed in the studied section of Jeribe

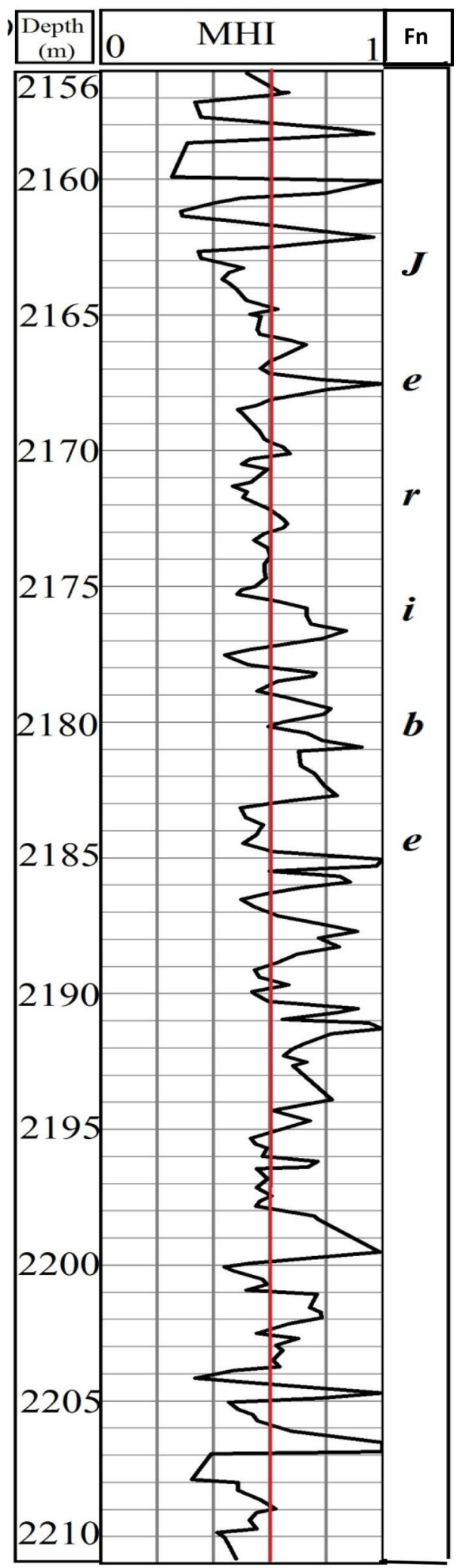

Fig. 6 Movable Hydrocarbon Index (MHI) curve for the studied Jeribe Formation in the well Ja-49. The red line represents $0.6 \mathrm{MHI}$ value separating movable hydrocarbon zones $(\leq 0.6)$ from non-movable hydrocarbon zones $(>0.6)$ 
Formation, which means the oil column extends down to certain depth in the formations underlying Jeribe Formation.

Acknowledgements The authors would like to thank very much Northern Oil Company (NOC), Kirkuk, who provided the log data used in this study.

Open Access This article is distributed under the terms of the Creative Commons Attribution 4.0 International License (http://creativecomm ons.org/licenses/by/4.0/), which permits unrestricted use, distribution, and reproduction in any medium, provided you give appropriate credit to the original author(s) and the source, provide a link to the Creative Commons license, and indicate if changes were made.

\section{References}

Abdulla AS (2017) Reservoir characterization of the Middle Miocene Jeribe Formation from selected oil wells in Kurdistan Region/ Northern Iraq. M.Sc. thesis (unpublished), Sulaimani University, Sulaimani, Iraq

Al-Ameri TK, Zumberg J, Markarian ZM (2011) Hydrocarbons in the Middle Miocene Jeribe Formation Dyala Region, NE Iraq. J Pet Geol 34(2):199-216

Al-Dabbas MA, Al-Sagri KEA, Al-Jassim JA, Al-Jwaini YS (2012) Sedimentological and diagenetic study of the Early Middle Miocene Jeribe Limestone Formation in selected wells from Iraq northern oilfields (Ajil; Hamrin; Jadid; Khashab). J Baghdad Sci 10(1):207-216

Al-Jwaini YS, Gayara AD (2016) Upper Palaeogene-Lower Neogene Reservoir characterization in Kirkuk, Bai Hassan and Khabaz Oil Fields, Northern Iraq. Tikrit J Pure Sci 21(3):82-101

Aqrawi AAM, Goff JC, Horbury AD, Sadooni FN (2010) Petroleum geology of Iraq. Scientific Press, Beaconsfield

Archie GE (1942) The electrical resistivity log as an aid in determining some reservoir characteristics. Trans AIME 146(01):54-62

Asquith GB (1985) Handbook of log evaluation techniques for carbonate reservoirs. AAPG, Tulsa

Asquith GB, Gibson CR (1982) Basic well analysis for geologist. AAPG, Tulsa

Asquith G, Krygowski D (2004) Basic well log analysis, AAPG methods in exploration 16. AAPG, Tulsa

Baban DH, Hussein HS (2016) Characterization of the Tertiary reservoir in Khabbaz Oil Field, Kirkuk area, Northern Iraq. Arab J Geosci 9:237. https://doi.org/10.1007/s12517-015-2272-y

Banks G (2011) Deciphering the fracture networks of carbonate reservoirs in northern Iraq. http://www.westernzagros.com. Accessed 15 May 2016

Bassiousi Z (1994) Theory, Measurement, and Interpretation of Well Logs. Society of Petroleum Engineers, Richardson

Bateman RM (1985) Open-hole log analysis and formation evaluation, 137 Newbury Street, Boston, USA

Buday T (1980) Regional geology of Iraq, Volume I: stratigraphy and paleontology. Dar Al-Kutib publishing house. University of Mosul, Mosul

Buday T, Jassim SZ (1987) Regional geology of Iraq, Volume II: tectonic, magmatism, and metamorphism. Dar Al-Kutib publishing house. University of Mosul, Mosul
Fadhil TD (2013) Sedimentological and reservoir characterization for Jeribe formation at Alass Dome/North Hamrin Oil Field. M.Sc. thesis (unpublished), University of Tikrit, Tikrit, Iraq

Gharib AF (2012) Sedimentological and reservoir characterization of euphrates and Jeribe formations in selected wells in Ajeel Oil Field/Northern Iraq. M.Sc. thesis (unpublished), University of Tikrit, Tikrit, Iraq

HLS (2007) Basic Log Interpretation, Log Interpretation Seminar, New Delhi

Hussein HS (2015) Characterization of the tertiary reservoirs in Khabbaz Oil Field, Kirkuk Area, Northern Iraq. M.Sc. thesis (unpublished), Sulaimani University, Sulaimani, Iraq

Ibrahim DM (2008) Sedimentology and reservoir characteristics of Jeribe Formation (Middle Miocene) in Tawke Oil Field, Zakho, Kurdistan Region-Iraq. M.Sc. thesis (unpublished), Salahaddin University, Erbil, Iraq

Jassim SZ, Buday T (2006) Latest Eocene-Recent Megasequence AP119(Chapter 14). In: Jassim SZ, Goff JC (eds) Geology of Iraq. Dolin, Prague and Moravian MuseumBrno, Brno, pp 169-184

Jassim SZ, Al-Gailani M (2006) Hydrocarbons (Chapter 18). In: Jassim SZ, Goff JC (eds) Geology of Iraq. Dolin, Prague and Moravian MuseumBrno, Brno, pp 169-184

Johnson DE, Pile KE (2006) Well logging in nontechnical language, 2nd edn. Penn Well, Tulsa

Krygowsky DA (2003) Guide to petrophysical interpretation. Texas, USA

Markaryan ZM (2005) Hydrocarbon generation, migration pathways and their accumulation of the Jeribe Formation in NE Iraq. M.Sc. thesis (unpublished), University of Baghdad, Baghdad, Iraq

Mohammadamin DH (1989) Biostratigraphy of Garagu Formation in selected wells from Northern Iraqi Oil Fields. M.Sc. thesis (unpublished), University of Baghdad, Baghdad, Iraq

Prazak J (1974) Stratigraphy and paleontology of the miocene of the Western Desert, W. Iraq, Manuscript report, GUESURV. Baghdad. Iraq

Schlumberger (1989) Log Interpretation Principles/Applications, Schlumberger Wireline \& Testing, 225 Schlumberger Drive. Sugar Land, Texas, USA

Serra O, Serra L (2004) well logging-data acquisition and applications. Serralog, France

Sissakian VK, Karim SA, Al-Kubaisyi KN, Al-Ansari N, Knutsson S (2016) The miocene sequence in iraq, a review and discussion, with emphasize on the stratigraphy. Paleogeogr Econ Potential J Earth Sci Geotech Eng 6(3):271-317

Sun SQ, Esteban M (1994) Plaeoclimatic controls on sedimentations, diagenesis, and reservoir quality: lessons from miocene carbonates. AAPG Bull 78:519-543

Van Bellen RC, Dunnington HV, Wetzel R, Morton D (1959) Lexique Stratigraphique International, Asia, Fscicule 10a, Iraq, Paris, France

Publisher's Note Springer Nature remains neutral with regard to jurisdictional claims in published maps and institutional affiliations. 